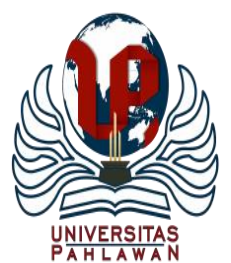

Edukatif : Jurnal Ilmu Pendidikan Volume 3 Nomor 4 Tahun 2021 Halm 1559 - 1567

EDUKATIF: JURNAL ILMU PENDIDIKAN

Research \& Learning in Education

https://edukatif.org/index.php/edukatif/index

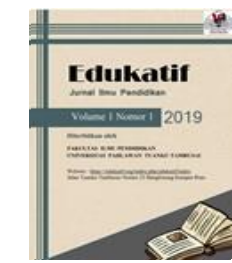

\title{
Pengaruh Kesiapan Pembelajaran Jarak Jauh Terhadap Hasil Belajar Peserta Didik Selama Pandemi Covid-19 Pada Mata Pelajaran Ekonomi Di SMA
}

\author{
Siti Nurrahmawati ${ }^{1 凶}$, Riza Yonisa Kurniawan ${ }^{2}$ \\ Universitas Negeri Surabaya, Indonesia ${ }^{1,2}$ \\ E-mail : nurarahmawati0@ gmail.com ${ }^{1}$, rizakurniawan@ @unesa.ac.id ${ }^{2}$
}

\begin{abstract}
Abstrak
Penelitian ini bertujuan untuk mengetahui pengaruh kesiapan pembelajaran jarak jauh terhadap hasil belajar peserta didik selama pandemi Covid-19 pada mata pelajaran ekonomi kelas X di SMA Negeri 1 sale yang berada di kapubaten Rembang. Jenis penelitian ini menggunakan penelitian korelasional dengan menggunakan pendekatan kuantitatif. Dibuktikan dengan nilai koefisien determinasi yang diperoleh dari uji statistik sebesar 0,064. Nilai tersebut menunjukkan adanya sumbangsih antara kesiapan pembelajaran jarak jauh dengan hasil belajar sebesar 6,4\% dan sebesar 93,6\% dipengaruhi oleh variabel yang tidak ada dalam penelitian ini. Diperkuat lagi pada hasil nilai koefisien regresi yang memperoleh hasil koefisien positif sebesar 0,115 , yang berarti uji regresi linier sederhana menunjukkan nilai positif sehingga dapat ditarik kesimpulan bahwa ada pengaruh positif antara variabel independen (X) terhadap variabel dependen (Y). Kemudian hasil pada uji t diketahui nilai signifikansi sebesar 0,013 < 0,05 yang berarti bahwa variabel bebas $(\mathrm{X})$ terhadap variabel terikat $(\mathrm{Y})$ berpengaruh secara parsial. Sedangkan hasil pada uji $\mathrm{F}$ telah diketahui nilai signifikansi yang sama yaitu sebesar 0,013 < 0,05 yang berarti kesiapan pembelajaran jarak jauh $(\mathrm{X})$ terhadap hasil belajar $(\mathrm{Y})$ dinyatakan berpengaruh secara simultan.
\end{abstract}

Kata Kunci: Kesiapan, Pembelajaran Jarak Jauh, Hasil Belajar

\begin{abstract}
This study aims to determine the effect of distance learning readiness on student learning outcomes during the covid-19 pandemic in class X economics subjects at SMA Negeri 1 Sale in Rembang Regency. This type of research uses correlational research using a quantitative approach. It is evidenced by the coefficient of determination obtained from statistical tests of 0.064. This value indicates that there is a contribution between distance learning readiness and learning outcomes of $6.4 \%$ and $93.6 \%$ is influenced by variables that are not in this study. Reinforced again in the results of the regression coefficient which obtained a positive coefficient of 0.115, which means the simple linear regression test shows a positive value so that it can be concluded that there is a positive effect between the independent variable $(X)$ on the dependent variable $(Y)$. Then the results of the t test are known to have a significance value of $0.013<0.05$, which means that the independent variable $(X)$ on the dependent variable ( $Y$ ) has a partial effect. Meanwhile, the results of the $F$ test have known the same significance value, which is $0.013<0.05$, which means that distance learning readiness $(X)$ on learning outcomes $(Y)$ is declared to have a simultaneous effect.
\end{abstract}

Keywords: Readiness, E-Learning, Learning Result

Copyright (c) 2021 Siti Nurrahmawati, Riza Yonisa Kurniawan

$\triangle$ Corresponding author:

Email : nurarahmawati0@gmail.com

DOI : https://doi.org/10.31004/edukatif.v3i4.616

ISSN 2656-8063 (Media Cetak)

ISSN 2656-8071 (Media Online)

Edukatif : Jurnal Ilmu Pendidikan Vol 3 No 4 Tahun 2021 p-ISSN 2656-8063 e-ISSN 2656-8071 
1560 Pengaruh Kesiapan Pembelajaran Jarak Jauh Terhadap Hasil Belajar Peserta Didik Selama Pandemi Covid-19 Pada Mata Pelajaran Ekonomi Di SMA - Siti Nurrahmawati, Riza Yonisa Kurniawan DOI: https://doi.org/10.31004/edukatif.v3i4.616

\section{PENDAHULUAN}

Tahun 2020 telah dikejutkan adanya sebuah wabah penyakit yang melanda seluruh dunia, tidak terkecuali Indonesia. Wabah penyakit ini berdampak pada segala aspek kehidupan di Indonesia maupun di seluruh dunia. Wabah penyakit tersebut yaitu Virus Corona (Corona Virus) atau biasa disebut Covid-19. (World Healt Organization, 2020), mengatakan, "Coronavirus adalah suatu kelompok virus yang dapat menyebabkan penyakit pada hewan atau manusia. Beberapa jenis coronavirus diketahui menyebabkan infeksi saluran nafas pada manusia mulai dari batuk pilek hingga yang lebih serius seperti Middle East Respiratory Syndrome (MERS) dan Severe Acute Respiratory Syndrome (SARS). Coronavirus jenis baru yang ditemukan menyebabkan penyakit COVID-19”. Penyebaran covid-19 yang semakin tinggi, membuat pemerintah segera menekan laju penyebaran virus corona dengan berbagai cara mengubah tatanan kehidupan seperti pembatasan aktivitas sosial berskala besar (Social Distancing). Hal ini tentunya berakibat buruk bagi berbagai aspek kehidupan. Salah satunya yaitu pendidikan, adanya penyebaran virus corona membuat proses pembelajaran di Sekolah menjadi terhambat. Namun pemerintah selalu memiliki cara bagaimana seluruh aktivitas belajar pendidik dan peserta didik di Indonesia terus berjalan tanpa harus kontak fisik maupun kontak langsung, pemerintah juga berusaha tetap menjaga kualitas pendidikan ditengah pandemi yaitu dengan cara melaksanakan Pembelajaran Jarak Jauh. Sesuai dengan berlakunya surat edaran yang dibuat oleh Kementrian Pendidikan dan Kebudayaan Republik Indonesia (2020) nomor 4 tahun 2020 tentang "Pelaksanaan Kebijakan Pendidikan Dalam Masa Darurat Penyebaran Corona virus Desease (Covid- 19”, khususnya pada poin 2 yang menjelaskan bahwa pada intinya segala aktivitas belajar dilakukan dari rumah melalui pembelajaran jarak jauh.

Peraturan baru yang dikeluarkan pemerintah tentunya juga memberikan pengaruh terhadap proses pembelajaran karena tidak semua sekolah siap dan mampu menghadapi perubahan yang ada sehingga tujuan dari pembelajaran tidak berjalan dengan maksimal. Hal ini juga berdampak pada kesiapan belajar peserta didik, dimana yang biasanya mereka melakukan pembelajaran secara tatap muka kini harus melaksanakan pembelajaran secara jarak jauh. Menurut (Slameto, 2015), "kesiapan adalah keseluruhan kondisi seseorang yang membuatnya siap untuk memberi respon/jawaban di dalam cara tertentu terhadap suatu situasi". Pembelajaran jarak jauh menurut Tsai 2016 dalam (Churiyah et al., 2020) bahwa pembelajaran online juga disebut pembelajaran jarak jauh. Model pembelajaran ini menggambarkan upaya memberi akses belajar bagi guru dan siswa yang terkendala oleh jarak geografis, sehingga dalam Proses pembelajaran membutuhkan sistem komunikasi interaktif yang menghubungkan keduanya dengan berbagai sumber dibutuhkan di dalamnya. Kemudian menurut (Yunitasari \& Hanifah, 2020), "pembelajaran daring bukan sekedar materi yang dipindah melalui media internet, bukan juga sekedar tugas dan soal-soal yang dikirimkan melalui sosial media. Pembelajaran daring harus direncanakan, dilaksanakan, dan dievaluasi sama halnya dnegan pembelajaran yang terjadi di kelas".

Selain itu kesiapan pendidik, fasilitas sekolah serta orang tua juga diperlukan dalam menghadapi perubahan. Yang menjadi sorotan dalam kesiapan belajar salah satunya yaitu bagi peserta didik yang baru saja lulus Sekolah Menengah Pertama, dimana mereka akan menginjakkan kaki di jenjang Sekolah Menengah Atas. Perubahan lingkungan belajar disertai penerapan pembelajaran jarak jauh tentu membuat peserta didik kelas X memerlukan kesiapan yang tinggi karena mereka harus beradaptasi dengan perubahan kondisi dan lingkungan sekolah baru. Hal ini dibuktikan dengan adanya hasil wawancara kepada beberapa guru di SMA Negeri 1 Sale yang mengatakan banyak faktor yang menghambat kesiapan peserta didik dalam melaksanakan pembelajaran jarak jauh, salah satunya keterbatasan akses internet karena sebagian besar rumah peserta didik terkendala sinyal, mengingat daerah Sale merupakan kecamatan yang paling ujung dari kabupaten Rembang. Bahkan menurut keterangan yang disampaikan guru SMA Negeri Sale, pada awal pelaksanaan pembelajaran jarak jauh, ada peserta didik kelas X yang mengalami kendala berupa tidak memilki SmartPhone. Banyak juga 
1561 Pengaruh Kesiapan Pembelajaran Jarak Jauh Terhadap Hasil Belajar Peserta Didik Selama Pandemi Covid-19 Pada Mata Pelajaran Ekonomi Di SMA - Siti Nurrahmawati, Riza Yonisa Kurniawan DOI: https://doi.org/10.31004/edukatif.v3i4.616

yang merasakan keberatan dalam membeli paket internet sebelum pada akhirnya pemerintah sudah menyediakan paket internet. Yang lebih mengagetkan lagi, ada peserta didik yang memutuskan untuk bekerja karena menurutnya pembelajaran secara daring bisa dilakukan dimanapun dan kapanpun mereka berada, selain itu alasan mereka bekerja karena mereka cenderung bosan melaksanakan pembelajaran jarak jauh, sehingga mereka memilih melakukan kegiatan lain. Selain permasalahan yang dialami peserta didik, pendidik juga mengaku bahwa beberapa dari beliau belum sepenuhnya menguasai teknologi sehingga dalam membuat materi serta membuat perubahan perangkat pembelajaran menjadikan guru kurang memiliki kesiapan yang matang.

Permasalahan tersebut hampir sama dengan tesis yang ditulis (Sya'dullah, 2020), bahwa "Yang menjadi permasalahan mendasar dalam sistem adalah ketidaksiapan guru dan murid dalam melaksanakan pembelajaran jarak jauh, dari perubahan RPP yang harus menjadi pegangan guru dalam penyampaian pembelajaran, penyampaian tugas ataupun informasi ke siswa, feed back siswa kepada guru, hingga tahap penilaian yang juga membutuhkan waktu lebih lama. Masih ditambah dengan ketersediaan perangkat atau alat dalam pengerjaan tugas jarak jauh. Masih banyak siswa yang belum memiliki android atau alat, ada siswa yang signal jaringan provider tidak ada. Ekonomi orang tua yang menjadi tidak stabil karena Covid-19 menjadikan anggaran untuk pembelian paket data menjadi berkurang, bahkan banyak yang tidak sanggup untuk membeli paket data". Kemudian dipertegas lagi oleh penelitian (Churiyah et al., 2020) dimana hasil yang diperoleh dalam penelitiannya, yaitu bahwa sebenarnya infrastruktur virtual di Indonesia telah disiapkan dengan baik, namun faktor guru dan sekolah masih perlu memahami lebih jauh tentang esensi pembelajaran jarak jauh. Siswa memiliki kemandirian belajar yang rendah sehingga kurang mampu mengatur kegiatan belajar jarak jauh, sementara guru cenderung gagap tentang teknologi, dan orang tua masih kurang memahami sifat kegiatan belajar mengajar yang dilakukan di rumah.

Penerapan Pembelajaran Jarak Jauh saat pandemi Covid-19 berkaitan dengan kesiapan belajar yang tidak terlepas dari penentuan hasil belajar peserta didik. Yang menjadi sebuah landasan atau tolak ukur kemampuan peserta didik dalam mengikuti proses pembelajaran yaitu hasil belajar, mengingat hasil wawancara dengan guru bahwa dengan diberlakukan pelaksanaan pembelajaran jarak jauh menjadikan nilai peserta sedikit menurun. (Purwanto, 2016) menjelaskan bahwa, "hasil belajar merupakan kemampuan yang diperoleh siswa setelah mengikuti proses belajar, yang dapat memberikan perubahan tingkah laku baik pengetahuan, pemahaman, sikap dan keterampilan siswa sehingga menjadi lebih baik dari sebelumnya".

Pembelajaran jarak jauh dilakukan pada seluruh mata pelajaran, tidak terkecuali mata pelajaran Ekonomi. Dimana dalam lingkup sekolah menengah atas tentunya terdapat mata pelajaran ekonomi, oleh karena itu mata pelajaran ekonomi menjadi pelajaran terpenting di kelas IPS, hal ini diperkuat oleh (Prahara, 2017), yang mengatakan"Pembelajaran ekonomi merupakan pembelajaran yang dinamis dan dekat dengan kehidupan sehari-hari siswa. Konsep kebutuhan, skala prioritas, kelangkaan, rasionalitas, pilihan, keuntungan, dan resiko adalah hal-hal yang sering dijumpai dalam kegiatan ekonomi serta diajarkan juga pada mata pelajaran ekonomi di jenjang pendidikan formal. Sehubungan dengan hal tersebut, maka mata pelajaran ekonomi harus diajarkan sesuai kebutuhan siswa untuk mengahadapi tantangan di kemudian hari”.

Problematika yang terjadi pada aspek pendidikan di tengah pandemi covid-19 ini, ada beberapa penelitian yang sebelumnya sudah dilakukan terkait kesiapan belajar peserta didik, diantaranya penelitian yang dilakukan (Jamal, 2020) yang berjudul "Analisis Kesiapan Pembelajaran E-Learning Saat Pandemi Covid-19 Di Smk Negeri 1 Tambelangan" dalam penelitiannya, Jamal menggunakan model Teddy \& Swatman (2006) menggunakan 6 aspek kesiapan, dan hasil penelitiannya mengatakan bahwa faktor kesiapan peserta didik dikategorikan siap namun masih membutuhkan sedikit peningkatan, kemudian faktor kesiapan guru, dukungan management, serta faktor budaya sekolah dikategorikan siap, dan dapat dilanjutkan. Hanya ada 1 faktor yang tidak siap dan perlu peningkatan yaitu faktor kecenderungan pembelajaran e-learning. Kesimpulan penelitian Jamal hanya berupa analisis kesiapan pembelajaran e-learning di masa pandemi Covid- 
1562 Pengaruh Kesiapan Pembelajaran Jarak Jauh Terhadap Hasil Belajar Peserta Didik Selama Pandemi Covid-19 Pada Mata Pelajaran Ekonomi Di SMA - Siti Nurrahmawati, Riza Yonisa Kurniawan DOI: https://doi.org/10.31004/edukatif.v3i4.616

19. Kemudian salah satu penelitian terdahulu terkait kesiapan belajar yaitu pada penelitian (Mulyani, 2013) yang berjudul, "Hubungan Kesiapan Belajar Siswa Terhadap Prestasi Belajar”, menyatakan bahwa adanya hubungan yang signifikan antara kesiapan belajar siswa dengan prestasi belajar. Kesimpulan dari penelitian tersebut menjelaskan bahwa kesiapan merupakan faktor terpenting dalam penentuan berhasil tidaknya peserta didik dalam belajar. Ditemukan hasil bahwa kesiapan belajar peserta didik cukup baik, sehingga prestasi belajar peserta didik pun cukup baik. Penelitian Mulyani dilakukan sebelum adanya pandemi Covid-19. Dari problematika dan hasil penelitian sebelumnya, menjadi sebuah perhatian peneliti untuk melakukan penelitian di SMA Negeri 1 Sale yang berlokasi di kecamatan Sale, Kabupaten Rembang, Jawa Tengah. Mengingat adanya hambatan yang dihadapi serta belum adanya penelitian yang dilakukan disana terkait kesiapan pembelajaran jarak jauh, maka peneliti melakukan sebuah penelitian tentang Pengaruh Kesiapan Pembelajaran Jarak Jauh terhadap Hasil Belajar Peserta Didik selama Pandemi Covid-19 pada Mata Pelajaran Ekonomi Kelas X di SMA Negeri 1 Sale, Kapubaten Rembang.

\section{METODE PENELITIAN}

Penelitian ini menggunakan jenis penelitian korelasional dengan menggunakan pendekatan kuantitatif. Menurut (Sugiyono, 2019) penelitian korelasional merupakan penelitian yang digunakan untuk mengetahui ada tidaknya hubungan antar dua variabel atau lebih dengan variabel lainnya. (Sugiyono, 2019) juga menjelaskan bahwa pendekatan kuantitatif lebih menekankan pada penggunaan angka-angka dalam data penelitiannya dan statistik sebagai analisisnya. Variabel Independen dalam penelitian ini adalah kesiapan pembelajaran jarak jauh (E-Learning Readiness) dan variabel dependen adalah hasil belajar. Subjek penelitian ini yaitu 95 peserta didik seluruh kelas X IPS di SMA Negeri 1 Sale diambil dari jumlah populasi sebanyak 125 peserta didik dengan menggunakan sampling error sebesar 5\%. Penelitian dilakukan selama 2 minggu, di minggu pertama dilakukan uji validitas dan reliabilitas untuk mengukur kelayakan instrumen penelitian yang menggunakan skala likert dan minggu kedua dilakukan pengumpulan data untuk uji selanjutnya.

Penelitian ini menggunakan teknik pengumpulan data berupa wawancara yang dilakukan peneliti terhadap beberapa guru untuk mengetahui studi pendahuluan agar dapat mengetahui situasi yang dihadapi responden lebih dalam, selanjutnya digunakan teknik angket (kuesioner) yang menggunakan dengan menggunakan bantuan Google Form kemudian link Google Form disebarkan secara daring melalui grup WhatsApss kelas, penyebaran kuesioner digunakan untuk memperoleh data mengenai kesiapan pembelajaran jarak jauh selama Covid-19 pada peserta didik kelas X IPS di SMA Negeri 1 Sale, dan teknik dokumentasi yang digunakan untuk mencari data variabel hasil belajar berupa transkip nilai Ujian Akhir Semester Gasal peserta didik tahun ajaran 2020/2021.

Penelitian ini menggunakan teknik analisis yaitu analisis deskriptif. Kemudian dilakukan uji prasyarat analisis berupa uji normalitas, uji linieritas, uji heterokedastisitas, uji autokorelasi. selanjutnya dilakukan pengujian hipotesis yang menggunakan analisis uji regresi linier sederhana, dimana hasil akhir analisis berupa uji t, uji F, serta pengujian koefisien determinasi. Seluruh pengujian tersebut dilakukan dengan bantuan program SPSS Statistic 22.

\section{HASIL DAN PEMBAHASAN PENELITIAN}

\section{Hasil Validitas dan Reliabilitas}

Uji validitas dan reliabilitas dilakukan sebelum memulai penelitian melalui rumus rumus yang dikemukakan oleh Pearson dalam (Arikunto, 2019) yang dikenal sebagai rumus kolerasi Product Moment menggunakan bantuan program SPSS Statistic 22 untuk mengetahui kelayakan instrumen yang akan diujikan pada responden. Pengukuran indikator variabel kesiapan pembelajaran jarak jauh (X) sebanyak 37 butir soal telah diujicobakan kepada 67 responden yang dipilih secara acak. Uji validitas memperoleh hasil perbandingan antara nilai $r_{\text {hitung }}$ dengan $r_{\text {tabel }}$, dapat dirtarik kesimpulan bahwa semua butir soal untuk variabel 
1563 Pengaruh Kesiapan Pembelajaran Jarak Jauh Terhadap Hasil Belajar Peserta Didik Selama Pandemi Covid-19 Pada Mata Pelajaran Ekonomi Di SMA - Siti Nurrahmawati, Riza Yonisa Kurniawan DOI: https://doi.org/10.31004/edukatif.v3i4.616

$\mathrm{X}$ nilai $\mathrm{r}_{\text {hitung }}>\mathrm{r}_{\text {tabel }}$ 0,2404 maka dinyatakan VALID. Setelah dilakukan uji validitas, maka semua instrumen yang dikatakan valid selanjutnya dilakukan uji reliabilitas. Hasil pengujian reliabilitas, maka diketahui hasil X $=0,914>0,60$, artinya instrumen kesiapan pembelajaran jarak jauh (X) telah memenuhi nilai Cronbach's Alpha $>0,60$ sehingga instrumen tersebut dinyatakan RELIABEL.

\section{Hasil Analisis Deskriptif}

Penyajian deskripsi data diperoleh dari sampel melalui penelitian di lapangan yang sudah memenuhi syarat. Analisis statistik deskriptif meliputi pengujian modus, median, dan mean (rata-rata). Penyajian data pada analisis deskriptif ini menggunakan tabel distribusi frekuensi pada variabel $\mathrm{X}$ dan variabel Y. Berikut hasil distribusi frekuensi yang telah diolah peneliti:

Variabel Kesiapan Pembelajaran Jarak Jauh (X)

Variabel kesiapan pembelajaran jarak jauh diukur menggunakan 12 indikator dengan 37 item pernyataan yang diujikan kepada 95 responden. Berdasarkan data kesiapan pembelajaran jarak jauh di kelas X IPS SMAN Sale yang telah dilakukan distribusi frekuensi, maka diperoleh distribusi kecenderungan variabel sebagai berikut:

Tabel 1

Distribusi Kecenderungan Variabel Kesiapan Pembelajaran Jarak Jauh

\begin{tabular}{lllll}
\hline No. & Kelas Interval & Frekuensi & $\mathbf{F ~ ( \% )}$ & Kategori \\
\hline 1 & $\mathrm{X} \geq 111$ & 1 & $1 \%$ & Tinggi \\
\hline 2 & $74 \leq \mathrm{X}<111$ & 86 & $91 \%$ & Sedang \\
\hline 3 & $\mathrm{x}<74$ & 8 & $8 \%$ & Rendah \\
\hline
\end{tabular}

Sumber : data diolah peneliti

Hasil perhitungan dapat diketahui bahwa rata-rata (mean) variabel kesiapan pembelajaran jarak jauh sebesar 95,8 berada pada rentang nilai $74 \leq X<111$ yaitu berada di kategori sedang. Maka dapat disimpulkan bahwa kesiapan pembelajaran jarak jauh peserta didik pada mata pelajaran ekonomi di kelas X IPS adalah sedang atau bisa dikatakan cukup baik.

Variabel Hasil Belajar (Y)

Data hasil belajar peserta didik diperoleh dari nilai hasil Ujian Akhir Semester Gasal pada Mata Pelajaran Ekonomi peserta didik kelas X IPS SMA Negeri 1 Sale sesuai dengan proporsi sampel yang telah ditentukan. Nilai hasil ujian peserta didik sudah dilakukan distribusi frekuensi, maka diperoleh distribusi kecenderungan variabel sebagai berikut:

Tabel 2

Distribusi kecenderungan variabel Hasil Belajar

\begin{tabular}{lllll}
\hline No. & Kelas Interval & Frekuensi & F $(\%)$ & Kategori \\
\hline 1 & $\mathrm{X} \geq 89$ & 18 & 18,9 & Tinggi \\
\hline 2 & $78 \leq \mathrm{X}<89$ & 72 & 75,8 & Sedang \\
\hline 3 & $\mathrm{X}<78$ & 5 & 5,3 & Rendah \\
\hline
\end{tabular}

Sumber : data diolah peneliti

Hasil perhitungan dapat diketahui bahwa rata-rata (mean) variabel hasil belajar sebesar 83,82 berada pada rentang nilai $78 \leq \mathrm{X}<89$ yaitu berada di kategori sedang. Maka dapat ditarik kesimpulan bahwa hasil belajar peserta didik pada mata pelajaran ekonomi di kelas X IPS adalah sedang atau bisa dikatakan cukup baik.

\section{Uji Prasyarat Analisis}

Uji prasyarat analisis dilakukan menggunakan bantuan program SPSS statistics 22. Pada uji normalitas yang dilakukan dengan metode Kolmogorov Smirnow, diketahui nilai signifikansi sebesar 0,075 sehingga 
1564 Pengaruh Kesiapan Pembelajaran Jarak Jauh Terhadap Hasil Belajar Peserta Didik Selama Pandemi Covid-19 Pada Mata Pelajaran Ekonomi Di SMA - Siti Nurrahmawati, Riza Yonisa Kurniawan DOI: https://doi.org/10.31004/edukatif.v3i4.616

$0,075>0,05$, maka dapat ditarik kesimpulan bahwa data telah terdistribusi normal. Uji linieritas dilakukan dengan melihat besarnya nilai signifikansi pada Deviation From Linierity, telah diketahui bahwa bahwa nilai sig. pada Deviation From Liniarity masing-masing variabel independen dan variabel dependen yaitu sebesar 0,260, sehingga 0,260 >0,05 maka dapat ditarik kesimpulan bahwa terdapat hubungan yang linier antara variabel independen dan variabel dependen. Uji heterokedastisitas dilakukan melalui uji Glejser, diketahui nilai signifikansi sebesar 0,712 sehingga 0,712>0,05, maka dapat ditarik kesimpulan bahwa tidak terjadi heterokedastisitas (terjadi homoskedastisitas). Uji autokorelasi dilakukan melalui metode Durbin Watsons, telah diketahui bahwa nilai 1,687 $<2,137<2,313$ sesuai dengan ketentuan uji hipotesis bahwa H0 diterima jika Du $<$ Dw $<4$-Du. Sehingga dapat dikatakan bahwa tidak terjadi autokorelasi.

\section{Regresi Linier Sederhana}

Uji regresi linier sederhana digunakan untuk menguji sejauh mana hubungan sebab akibat antara variabel independen dan variabel dependen. Analisis regresi linier berganda diuji menggunakan bantuan program SPSS Satatitics 22. Berikut tabel hasil uji regresi linier sederhana yang telah diolah peneliti :

Tabel 3

Uji Regresi Linier Sederhana

\begin{tabular}{ll|l|l|l|lll}
\hline \multirow{2}{*}{ Model } & \multicolumn{2}{|l|}{$\begin{array}{l}\text { Unstandardized } \\
\text { Coefficients }\end{array}$} & \multicolumn{2}{l|}{$\begin{array}{l}\text { Standardized } \\
\text { Coefficients }\end{array}$} & & \\
\cline { 2 - 5 } & B & Std. Error & Beta & t & Sig. \\
\hline $1 \quad \begin{array}{llllll}\text { (Constant) } \\
\text { Kesiapan } \\
\text { PJJ }\end{array}$ & 72,572 & 4,484 & & 16,186 &, 000 \\
\hline
\end{tabular}

Sumber : Hasil olah data SPSS oleh peneliti

Berdasarkan tabel diatas, diperoleh nilai Constant (a) sebesar 72,572. Sedang nilai variabel bebas (b/koefisien regresi) sebesar 0,115 . Maka persamaan regresi adalah $\mathrm{Y}=72,572+0,115 \mathrm{X}$. Interpretasi persamaan regresi linier sederhana berdasarkan tabel diatas yaitu 1) Konstanta sebesar 72,57, mengandung arti bahwa nilai konsisten variabel partisipasi adalah sebesar 72,57. 2) Koefisien regresi $X$ sebesar 0,115 menyatakan bahwa setiap penambahan $1 \%$ nilai variabel bebas, maka nilai variabel terikat bertambah sebesar 0,115. Koefien nilai tersebut memiliki nilai positif, sehingga dapat ditarik kesimpulan bahwa arah pengaruh variabel X terhadap Y yaitu Positif. 3) Dari tabel coefficients diperoleh nilai signifikansi sebesar 0,013<0,05, sehingga dapat ditarik kesimpulan bahwa variabel Kesiapan PJJ (X) berpengaruh terhadap variabel Hasil Belajar (Y). 4) Berdasarkan nilai $t$ dihasilkan $t_{\text {hitung }}$ sebesar 2,257 $>t_{\text {tabel }}$ 1,989 , sehingga dapat ditarik kesimpulan bahwa variabel Kesiapan PJJ (X) berpengaruh terhadap variabel Hasil Belajar (Y).

\section{Uji t}

Berdasarkan tabel diatas, dapat diketahui bahwa variabel kesiapan pembelajaran jarak jauh (X) memiliki nilai signifikansi sebesar $0,013<0,05$ dan nilai $t_{\text {hitung }} 2,527>t_{\text {tabel }} 1,989$, maka dapat ditarik kesimpulan bahwa $\mathrm{H} 0$ ditolak dan Ha diterima yang artinya terdapat pengaruh secara parsial antara variabel kesiapan pembelajaran jarak jauh (X) terhadap hasil belajar (Y).

\section{Uji F}

Berdasarkan olah data peneliti, diketahui bahwa nilai signifikansi untuk pengaruh variabel kesiapan pembelajaran jarak jauh $(\mathrm{X})$ terhadap variabel hasil belajar $(\mathrm{Y})$ adalah sebesar $0,013<0,05$ dan nilai Fhitung 6,385 > Ftabel 3,94. Sehingga dapat ditarik kesimpulan bahwa H0 ditolak dan Ha diterima yang berarti terdapat pengaruh antara variabel $\mathrm{X}$ dan $\mathrm{Y}$. 
1565 Pengaruh Kesiapan Pembelajaran Jarak Jauh Terhadap Hasil Belajar Peserta Didik Selama Pandemi Covid-19 Pada Mata Pelajaran Ekonomi Di SMA - Siti Nurrahmawati, Riza Yonisa Kurniawan DOI: https://doi.org/10.31004/edukatif.v3i4.616

\section{Koefisien Determinasi}

Hasil analisis data menunjukkan besarnya nilai korelasi $(\mathrm{R})$ adalah sebesar 0,253 . Dari data output yang telah diolah peneliti, maka diperoleh koefisien determinasi (R Square) sebesar 0,064 yang memilki arti bahwa pengaruh variabel bebas (Kesiapan PJJ) terhadap variabel terikat (Hasil Belajar) yaitu sebesar 6,4\% dan sebesar 93,6\% dipengaruhi oleh variabel lain yang tidak ada di dalam penelitian ini.

\section{Pembahasan}

Berdasarkan hasil analisis uji regresi linier sederhana yang telah diolah oleh peneliti untuk mengetahui adanya pengaruh parsial antara variabel kesiapan pembelajaran jarak jauh $(\mathrm{X})$ dan variabel hasil belajar (Y) pada mata pelajaran ekonomi di kelas X IPS SMA Negeri 1 Sale, diperolah data yang menunjukkan bahwa adanya pengaruh yang positif antara kesiapan pembelajaran jarak jauh (X) dan variabel hasil belajar (Y). Hal tersebut dilihat dari nilai $t_{\text {hitung }} 2,527>t_{\text {tabel }} 1,989$ atau nilai signifikansi sebesar 0,013 $<0,05$ sehingga dapat disimpullkan bahwa HO ditolak dan Ha diterima yang berarti terdapat pengaruh signifikan dan positif antara variabel kesiapan pembelajaran jarak jauh $(\mathrm{X})$ terhadap hasil belajar $(\mathrm{Y})$. Variabel kesiapan pembelajaran jarak jauh (X) terhadap hasil belajar (Y) memilki pengaruh signifikan sebesar 6,4\%. Yang berarti bahwa 93,6\% sisanya lebih banyak dipengaruhi oleh variabel lain yang tidak ada di dalam penelitian ini.

Hasil penelitian ini selaras dan dapat memperkuat penelitian yang dilakukan sebelumnya oleh (Mulyani, 2013) yang menyatakan bahwa adanya hubungan yang signifikan antara kesiapan belajar siswa dengan prestasi belajar. Kesimpulan dari penelitian tersebut menjelaskan bahwa kesiapan merupakan faktor terpenting dalam penentuan berhasil tidaknya peserta didik dalam belajar. Ditemukan hasil bahwa kesiapan belajar peserta didik cukup baik, sehingga prestasi belajar peserta didik pun cukup baik. Penelitian tersebut dengan penelitian ini memiliki perebedaan yang terletak pada sistem pembelajarannya, dimana penelitian tersebut sistem pembelajaran dilakukan secara tatap muka, sedangkan dalam penelitian ini menggunakan sistem berbasis teknologi atau daring.

Selanjutnya hasil penelitian (Umam, 2015) hasil analisis yang dilakukan diperoleh hasil skor sebesar 45,247 > 3,99 pada taraf signifikansi 0,05. Maka hipotesis nol (H0) ditolak yang berarti terdapat pengaruh kesiapan belajar terhadap hasil belajar. $\mathrm{R}$ square yang diperoleh dari penelitian tersebut sebesar 0,410 yang memiliki arti bahwa besaran pengaruh antara kesiapan belajar peserta didik dan hasil belajar yaitu sebesar 41,00\%. Selain berbeda pada taraf persentase pengaruhnya, perbedaannya juga terdapat pada sistem pembelajarannya, dimana penelitian tersebut dilakukan jauh sebelum adanya pandemi Covid-19 sehingga masih memakai sistem tatap muka. Sedangkan penelitian ini menggunakan sistem pembelajaran jarak jauh atau biasa disebut daring.

Penelitian sebelumnya juga dilakukan (Antara et al., 2014). Hasil penelitiannya menunjukkan bahwa adanya pengaruh secara simultan antara kesiapan (readiness) belajar Siswa dan transfer belajar terhadap hasil belajar Siswa. Hasil temuan penelitian tersebut memperkuat penelitian ini bahwa adanya pengaruh antara kesiapan belajar dan hasil belajar. Hanya saja pada penelitian sebelumnya tidak menggunakan variabel kesiapan saja namun juga terdapat variabel transfer belajar. Penelitian ini pun dilakukan sebelum adanya Covid-19.

Penelitian ini menggunakan pengukuran berdasarkan indikator kesiapan pembelajaran jarak jauh (Elearning Readiness) yang dikemukakan oleh (Mercado, 2008), diantaranya yaitu penggunaan akses teknologi (Technology Access) berupa akses komputer, konektivitas internet, alat/aplikasi pendukung, kemudian keterampilan teknologi (Technology Skills) berupa keterampilan dasar komputer, keterampilan dasar internet, literasi tentang Aplikasi Perangkat Lunak, dan sikap siswa terhadap E-learning (Students' Attitude towards eLearning) berupa kebiasaan belajar, kemampuan, motivasi, manajemen waktu, dan ada tambahan indikator yang mampu mengukur kesiapan pembelajaran jarak jauh yang telah dikemukakan oleh (Doculan, 2014) yaitu berupa dukungan sosial (Social Support), dan manfaat yang dirasakan (Perceived Usefulness). Dari hasil 
1566 Pengaruh Kesiapan Pembelajaran Jarak Jauh Terhadap Hasil Belajar Peserta Didik Selama Pandemi Covid-19 Pada Mata Pelajaran Ekonomi Di SMA - Siti Nurrahmawati, Riza Yonisa Kurniawan DOI: https://doi.org/10.31004/edukatif.v3i4.616

penelitian menunjukkan keseluruhan indikator dapat berkontribusi dalam menjelaskan variabel kesiapan pembelajaran jarak jauh.

Berdasarkan rata-rata kuisioner yang diberikan kepada responden, sebagian besar mereka sudah memiliki teknologi dan aplikasi yang mampu menunjang pembelajaran jarak jauh, namun dalam keterampilan teknologi sebagian besar mereka belum bisa menggunakan fasilitas belajar seperti mengakses perpustakan online. Maka diperlukan pelatihan pagi peserta didik dalam mengakses materi yang dibutuhkan secara online agar dapat mencapai pembelajaran jarak jauh dengan maksimal.

Kemudian dalam indikator kebiasaan belajar dan manajemen waktu, sebagian besar responden sudah memiliki kesiapan yang matang dalam melaksanakan pembelajaran jarak jauh. Sebagian besar responden memiliki kemampuan serta motivasi yang baik dalam mengikuti pembelajaran jarak jauh seperti kemampuan mudah beradaptasi dalam menghadapi perubahan yang ada, mereka juga memiliki motivasi yang cukup baik dalam belajar meskipun dalam keadaan adanya pandemi Covid-19. Namun sebagian dari mereka merasa bahwa pembelajaran secara online membuat mereka sedikit sulit menerima materi karena sudah terbiasa dengan pembelajaran tatap muka. Maka diperlukan inovasi pada penyampaian materi. Seperti pemanfaatan teknologi berupa media video yang mampu mengadaptasikan perangkat yang sudah ada, seperti penelitian (Febriantika et al., 2021) yang menghasilkan temuan bahwasanya media video animasi mampu menarik belajar peserta didik, dengan adanya hal tersebut peserta didik akan lebih senang, tertarik dan lebih memperhatikan penyampaian materi.

Orang tua, guru, serta sekolah sudah memberikan dukungan serta fasilitas yang baik untuk responden, namun lingkungan rumah sebagian besar responden sangat mengganggu aktivitas belajar para responden. Dalam hal ini dibutuhkan kemandirian peserta didik untuk dapat memecahkan masalahnya sehingga mereka dapat meminimalisir gangguan tersebut.

Berdasarkan hasil distribusi kecenderungan variabel kesiapan pembelajaran jarak jauh didapatkan hasil skor rata-rata sebesar 95,8 yaitu berada di kategori sedang. Maka dapat disimpulkan bahwa kesiapan pembelajaran jarak jauh peserta didik pada mata pelajaran ekonomi di kelas X IPS adalah sedang atau bisa dikatakan cukup baik. Sedangkan hasil belajar yang diperoleh responden dari nilai ujian akhir semester menunjukkan bahwa nilai rata-rata responden sebesar 83,82. Maka dapat ditarik kesimpulan bahwa hasil belajar peserta didik pada mata pelajaran ekonomi di kelas X IPS adalah sedang atau bisa dikatakan cukup baik, meskipun dalam situasi yang seperti ini.

Penelitian ini hanya meneliti pengaruh kesiapan pembelajaran jarak jauh terhadap hasil belajar peserta didik di masa pandemi Covid-19 pada mata pelajaran ekonomi, yang menunjukkan hasil kontribusi variabel kesiapan pembelajaran jarak jauh terhadap hasil belajar sebesar 6,4\%. Berarti bahwa sisa 93,6\% sebagian besar dipengaruhi oleh variabel lain yang tidak ada dalam penelitian ini. Maka diharapkan dalam penelitian selanjutnya dapat mengembangkan variabel lain yang dapat mempengaruhi hasil belajar pesert didik di masa pandemi Covid-19 ini.

\section{KESIMPULAN}

Berdasarkan kuisioner yang telah disebarkan kepada 95 responden, dapat disimpulkan bahwa sebagian besar peserta didik lebih menyukai pembelajaran tatap muka dibandingkan dengan pembelajaran jarak jauh atau secara online. Dalam pembelajaran tatap muka mereka lebih mudah menerima materi pelajaran ekonomi karena dengan begitu mereka dapat dibimbing guru secara langsung. Meskipun begitu, secara keseluruhan peserta didik telah memiliki kesiapan yang cukup untuk menghadapi pembelajaran jarak jauh. Hal ini dibuktikan dengan hasil olah data yang dilakukan peneliti, yang mengungkapkan bahwa kesiapan variabel pembelajaran jarak jauh peserta didik berada pada kategori sedang, kemudian pada variabel hasil belajar diketahui nilai rata-rata peserta didik berada dikategori sedang atau cukup baik, dan yang terakhir dari semua 
1567 Pengaruh Kesiapan Pembelajaran Jarak Jauh Terhadap Hasil Belajar Peserta Didik Selama Pandemi Covid-19 Pada Mata Pelajaran Ekonomi Di SMA - Siti Nurrahmawati, Riza Yonisa Kurniawan DOI: https://doi.org/10.31004/edukatif.v3i4.616

olah data yang dilakukan peneliti bahwa terdapat hubungan yang positif antara kesiapan pembelajaran jarak jauh terhadap hasil belajar peserta didik.

\section{DAFTAR PUSTAKA}

Antara, I. N. R., Haris, I. A., \& Nuridja, I. M. (2014). Pengaruh Kesiapan dan Transfer Belajar Terhadap Hasil Belajar Ekonomi di SMA Negeri 1 Ubud. Jurnal Pendidikan Ekonomi Undhiska, 4(1), 1-12. https://doi.org/http://dx.doi.org/10.23887/jjpe.v4i1.2014

Arikunto, S. (2019). Prosedur Penelitian Suatu Pendekatan Praktik. (15th ed.). Rineka Cipta.

Churiyah, M., Sholikhan, S., Filianti, F., \& Sakdiyyah, D. A. (2020). Indonesia Education Readiness Conducting Distance Learning in Covid-19 Pandemic Situation. International Journal of Multicultural and Multireligious Understanding, 7(6), 491. https://doi.org/10.18415/ijmmu.v7i6.1833

Doculan, J. A. D. (2014). E-Learning Readiness Assessment Tool For Philippine Higher Education Institutions. 7(3), 1-9.

Febriantika, F., Fisabilillah, N., \& Sakti, N. C. (2021). Pengembangan Video Animasi Sebagai Upaya Peningkatan Minat Belajar Peserta Didik Materi Perpajakan di Sekolah Menengah Atas. Edukatif: Jurnal Ilmu Pendidikan, 3(4), 1271-1281.

Jamal, S. (2020). Analisis Kesiapan Pembelajaran E-Learning Saat Pandemi Covid-19 Di SMK Negeri 1 Tambelangan. 8, 16-22.

Kementrian Pendidikan dan Kebudayaan Republik Indonesia. (2020). SE Mendikbud: Pelaksanaan Kebijakan Pendidikan dalam Masa Darurat Penyebaran Covid-19.

https://www.kemdikbud.go.id/main/blog/2020/03/se-mendikbud-pelaksanaan-kebijakan-pendidikandalam-masa-darurat-penyebaran-covid19

Mercado, C. A. (2008). Readiness Assessment Tool for An eLearning Environment Implementation. Fifth International Conference on ELearning for Knowledge-Based Society, 2005, 1-11. https://citeseerx.ist.psu.edu/viewdoc/download?doi=10.1.1.588.5146\&rep=rep1\&type=pdf

Mulyani, D. (2013). Hubungan Kesiapan Belajar Siswa Dengan Prestasi Belajar. Konselor, 2(1), 27-31. https://doi.org/10.24036/0201321729-0-00

Prahara, R. S. (2017). Kualitas Pembelajaran Ekonomi Di Sekolah Menengah Atas Negeri (SMAN) Dan Madrasah Aliyah Negeri (MAN) Se-Malang Raya.

http://pasca.um.ac.id/repository/index.php/2017/02/08/kualitas-pembelajaran-ekonomi-di-sekolahmenengah-atas-negeri-sman-dan-madrasah-aliyah-negeri-man-se-malang-raya/

Purwanto. (2016). Evaluasi Hasil Belajar. Pustaka Pelajar.

Slameto. (2015). Belajar dan Faktor-Faktor yang Mempengaruhinya (6th ed.). Rineka Cipta.

Sugiyono. (2019). Metode Penelitian Kuantitatif, Kualitatif, dan R\&D (Sutopo (ed.); Kedua). Alfabeta.

Sya'dullah, M. (2020). Pandemi Covid-19 Dan Implikasinya Terhadap Pembelajaran Pendidikan Agama Islam (Studi Kasus Pada Siswa Smp N 1 Banyubiru Kabupaten Semarang) Tahun 2020. Institut Agama Islam Negeri (IAIN) Salatiga.

Umam, K. A. (2015). Pengaruh Kesiapan Belajar Terhadap Hasil Belajar Peserta Didik Program Paket C (Studi di Pusat Kegiatan Belajar Masyarakat Sunan Drajat Kecamatan Paciran Kabupaten Lamongan). Unuversitas Negeri Semarang.

World Healt Organization. (2020). Pertanyaan dan jawaban terkait Corona Virus. https://www.who.int/indonesia/news/novel-coronavirus/qa-for-public

Yunitasari, R., \& Hanifah, U. (2020). Pengaruh Pembelajaran Daring terhadap Minat Belajar Siswa pada Masa COVID-19. Edukatif: Jurnal Ilmu Pendidikan, 2(3), 232-243. 